\title{
PENGARUH PENGETAHUAN DAN POLA ASUH IBU TERHADAP STATUS GIZI BALITA DI POSYANDU TUNAS MELATI DESA LIMBUNG KECAMATAN SUNGAI RAYA KABUPATEN KUBU RAYA TAHUN 2020
}

\begin{abstract}
Windiyati $^{1}$
Akademi Kebidanan Panca Bhakti Pontianak

Email Korespondensi : akbidpbpontianak@gmail.com

Abstrak

Balita adalah periode emas, jendela peluang dan periode kritis. balita sebagai generasi masa depan yang potensial membutuhkan pertumbuhan dan perkembangan yang optimal dengan nutrisi yang tepat, stimulasi yang memadai. Berdasarkan studi pendahuluan pada dua Posyandu di Desa Limbung masih ada balita dengan gizi buruk. Sebanyak 35 (30,44\%) balita ditemukan kurang gizi di Posyandu Tunas Melati. Lebih tinggi jika dibandingkan dengan Posyandu Puring Kencana sebanyak 26 balita (19,80\%). Demikian pula, sebanyak 80 balita memiliki gizi yang baik di Posyandu Tunas Melati $(69,56 \%)$ lebih rendah jika dibandingkan dengan Posyandu Puring Kencana yang 104 balita (79,4\%). Tujuan dari penelitian ini adalah untuk mengetahui pengaruh pengetahuan ibu dan pengasuhan terhadap status gizi balita di Posyandu Tunas Melati Desa Limbung Kecamatan Sungai Raya Kecamatan Kubu Raya 2020 ". Kuasi Eksperimental digunakan dalam penelitian ini dengan One group pre test - post test Berdasarkan hasil penelitian ditemukan bahwa statistik pengetahuan ibu tentang gizi, pengasuhan ibu, pendidikan dan pekerjaan ibu, pengetahuan ibu lebih berpengaruh daripada ibu pengasuhan terhadap status gizi balita. dimana dari hasil analisis model bertahap diketahui bahwa variabel pengetahuan ibu memiliki nilai sig 0,000 , dan pola pengasuhan ibu memiliki nilai sig 0,02 , tetapi angka $t$ untuk pengetahuan ibu adalah 6,069 dan nilai t's pola pengasuhan ibu adalah 3,225, koefisien regresi untuk pengetahuan ibu adalah 0,574 dan untuk pengasuhan ibu adalah 0,263. Jadi dapat disimpulkan bahwa Pada nilai $t$, pengetahuan ibu lebih berpengaruh daripada gaya pengasuhan ibu pada status gizi anak balita. maka untuk persamaan regresi yang terbentuk adalah sebagai berikut: $\mathrm{Y}=0,184+0,574 \mathrm{X} 1+0,263 \mathrm{X} 2$. Petugas kesehatan diharapkan memberikan konseling kepada ibu nifas dan menekankan konseling tentang materi kolostrum, penggunaan kolostrum, manfaat menyusui, kejang.
\end{abstract}

Kata Kunci: Pengetahuan, Pola Asuh, Status Gizi

\begin{abstract}
Underfives is a golden period, a window of opportunity and a critical period. Underfives as potential future generations need optimal growth and development with appropriate nutrition, adequate stimulation. Based on preliminary studies on the two Posyandu in Limbung Village there are still underfives with malnutrition.As many as 35 (30.44\%) underfives was found under nutrition in Posyandu Tunas Melati. It higher when compared to Posyandu Puring Kencana as many as 26 underfives (19.80\%). Likewise, as many as 80 underfives have a good nutrition in Posyandu Tunas Melati (69.56\%) lower when compared to Posyandu Puring Kencana which was 104 underfives (79.4\%). The aim of this study is to find out the influence of mother's knowledge and parenting on the nutritional status of underfives in Posyandu Tunas Melati Limbung Village Sungai Raya subdistrict Kubu Raya district 2020 ". Quasi Experimental was used in this reasearch with One group pre test post test. Based on the results of the study found that the statistics of maternal knowledge about nutrition, maternal parenting, education and occupation of the mother, the mother's knowledge is more influential than parenting mother on the nutritional status of children under five. where from the results of the stepwise model analysis it is known that the mother's knowledge variable has a sig value of 0,000 , and the mother's parenting has a sig value of 0.02 , but the $t$ number for mother's knowledge is 6,069 and the value of t's mother's parenting is 3,225 , the regression coefficient for mother's knowledge is 0.574 and for maternal parenting is 0.263 . So it can be concluded that based on $t$ value, mother's knowledge is more influential than mother's parenting style on the nutritional status of underfives. then for the formed regression equation is as follows: $\mathrm{Y}=0.184+$ $0.574 \mathrm{X} 1+0.263 \mathrm{X} 2$. Health workers are expected to provide counseling to post partum mothers and emphasize counseling about colostrum material, the use of colostrum, the benefits of breastfeeding, seizures.
\end{abstract}

Keywords: Knowledge, Parenting, Nutritional Status

\footnotetext{
${ }^{1}$ Dosen Akademi Kebidanan Panca Bhakti Pontianak
} 


\section{Pendahuluan}

Masa balita adalah masa keemasan, jendela kesempatan dan masa kritis. Balita sebagai calon generasi penerus perlu pertumbuhan dan perkembangan yang optimal dengan gizi yang sesuai, stimulasi yang memadai, terjangkaunya pelayanan kesehatan yang berkualitas termasuk deteksi dan intervensi dini penyimpangan pertumbuhan perkembangan serta pengurangan berbagai faktor lingkungan yang mengganggu pertumbuhan dan perkembangan anak (Denis, 2002). Menurut WHO merekomendasikan empat hal penting yang harus dilakukan, diantaranya adalah pemberian ASI 30 menit pertama, ASI Eksklusif, Makanan Pendamping ASI dan pemberian ASI selama 24 bulan, karena usia $0-24$ bulan merupakan masa pertumbuhan dan perkembangan yang pesat.

Keberhasilan tumbuh kembang pada masa kanak-kanak menentukan kualitas sumberdaya manusia yang selanjutnya akan berpengaruh terhadap keberhasilan pembangunan nasional. Faktor utama yang mempengaruhi tumbuh kembang anak, diantaranya adalah faktor gizi, kesehatan dan praktek pengasuhan (caring), dimana ketiga faktor tersebut terkait satu sama lain dan harus dilaksanakan secara bersama-sama dan seimbang (Briawan \& Herawati 2005). Gizi merupakan salah satu masalah kesehatan di berbagai negara, baik di negara maju maupun di negara berkembang. Masalah gizi ini diikuti dengan semakin bertambahnya jumlah penduduk, sehingga kebutuhan pangan seharihari tidak dapat terpenuhi (Sari, 2011).

Data prevalensi gizi buruk mengalami penurunan dari 9,7\% di tahun 2005 menjadi 4,9\% di tahun 2011 dan diharapkan pada tahun 2015 pravelensi gizi buruk dapat turun menjadi $3,6 \%$. Walaupun terjadi penurunan gizi buruk di Indonesia, tetapi masih akan ditemui sekitar 3,7 juta balita yang mengalami masalah gizi (Minarto, 2011).

Status gizi anak merupakan salah satu penentu kualitas sumber daya manusia (SDM), sehingga anak yang memiliki status gizi baik merupakan aset dan investasi sumber daya manusia (SDM) dimasa mendatang, namun sebaliknya anak yang memiliki status gizi kurang merupakan permasalahan terhadap sumber daya manusia dimasa mendatang. Menurut Widodo (2009), Balita usia 2-5 tahun termasuk dalam kelompok rentan atau rawan gizi karena gizi merupakan faktor penting bagi kesehatan dan kecerdasan anak.

Adapun menurut Soetjiningsih (2008), jika pada usia ini status gizinya tidak dikelola dengan baik, maka dikemudian hari kemungkinan akan terjadi gangguan status gizi buruk dan selanjutnya akan sulit terwujudnya perbaikan kualitas sumber daya manusia dimasa yang akan datang. Oleh karena itu pada masa balita usia 2-5 tahun harus mendapatkan perhatian yang lebih dari orang tua terhadap kesehatannya terutama dalam pemberian makanan-makanan yang bergizi. Dalam masa pengasuhan, lingkungan pertama yang berhubungan dengan anak adalah orang 
tuanya, anak tumbuh dan berkembang di bawah asuhan dan perawatan orang tua oleh karena itu orang tua merupakan dasar pertama bagi pembentukan pribadi anak, melalui orang tua, anak beradaptasi dengan lingkungannya untuk mengenal dunia sekitarnya serta pola pergaulan hidup yang berlaku dilingkungannya. Dengan demikian dasar pengembangan dari seorang individu telah diletakkan oleh orang tua melalui praktek pengasuhan anak sejak ia masih bayi (Supanto, 1990).

Pola pengasuhan anak berupa sikap dan perilaku ibu atau pengasuh lain dalam hal kedekatannya dengan anak, memberikan makan, merawat anak, menjaga kebersihan, dan memberikan kasih sayang. Hal tersebut seluruhnya berhubungan dengan keadaan ibu dalam hal kesehatan, status gizi, pendidikan umum dan pengetahuan tentang pengasuhan anak yang baik serta sifat pekerjaan seharihari, karena kejadian kurang gizi pada anak sangat ditentukan oleh praktek pengasuhan dalam keluarga (Soekirman 2000). Penelitian Sandjaja (2000) tentang Penyimpangan Positif (Positive Deviance) Status Gizi Anak Balita Dan Faktor-Faktor Yang Berpengaruh Terjadinya Gizi Kurang Pada Balita di Kabupaten Sukabumi dan Gunung Kidul, memperoleh hasil bahwa pengetahuan gizi ibu tentang sumber vitamin dan mineral berperan nyata terhadap resiko terjadinya gizi kurang

Tabel 1 Data Balita dan Status Gizi Balita Di Posyandu Tunas Melati Tahun 2020

\begin{tabular}{cccccccc}
\hline \multirow{2}{*}{ Posyandu } & \multirow{2}{*}{$\begin{array}{c}\text { Jumlah } \\
\text { Balita }\end{array}$} & \multicolumn{2}{c}{ Gizi Baik } & \multicolumn{2}{c}{ Gizi kurang } & \multicolumn{2}{c}{ Gizi Buruk } \\
\cline { 3 - 8 } & & $\sum$ & $\%$ & $\sum$ & $\%$ & $\sum$ & $\%$ \\
\hline Tunas Melati & 115 & 80 & 69,56 & 35 & 30,44 & 0 & 0
\end{tabular}

pada balita di Kabupaten Sukabumi dan Gunung Kidul, karena semakin tinggi pengetahuan gizi ibu akan semakin baik pula praktek pengasuhan di tingkat rumah tangga sehingga dapat meningkatkan penyusunan menu keluarga dan dampaknya adalah meningkatnya kesejahteraan anggota keluarga, dengan demikian mencegah terjadinya gangguan gizi pada keluarga (Sediaoetama, 2006).

Dari hasil riset kesehatan dasar (Riskesdas) tahun 2010 dan 2014 menunjukan bahwa ditingkat nasional sudah terjadi penurunan prevalensi kurang gizi (berat badan menurut umur), penurunan terjadi pada prevalensi gizi buruk yaitu dari 5,4\% tahun 2010 menjadi 4,9\% tahun 2017 Adapun untuk prevalensi gizi kurang, tahun 2019 tidak terjadi penurunan, yaitu tetap $13,0 \%$, prevalensi pendek pada balita $35,7 \%$ menurun dari 36,7 $\%$ dari tahun 2019.

Berdasarkan data Penduduk, KK, Posyandu dan Balita di Desa Limbung Tahun 2020 menunjukkan bahwa Dusun Merdeka mempunyai 2 (dua) buah Posyandu yaitu Posyandu Tunas Melati dan Posyandu Puring Kencana, dan jumlah balita terbanyak setelah dusun limbung adalah Dusun Merdeka yaitu sebanyak 557 balita. Data yang diperoleh dari kedua Posyandu tersebut adalah sebagai berikut 


\begin{tabular}{lllllllll}
\hline Puring Kencana & 131 & 104 & 79,4 & 26 & 19,80 & 0 & 0 \\
\hline
\end{tabular}

Dari data tabel 1 kedua Posyandu di Desa Limbung masih terdapat balita dengan gizi kurang, Untuk Posyandu Tunas Melati balita gizi kurang sebanyak 35 orang (30,44 $\%)$ ini lebih tinggi bila dibanding dengan Posyandu Puring Kencana sebanyak 26 orang $(19,80 \%)$. Demikian juga untuk gizi baik di Posyandu Tunas Melati sebanyak 80 orang $(69,56 \%)$ lebih rendah bila disbanding dengan Posyandu Puring Kencana yaitu sebanyak 104 orang $(79,4 \%)$.

Untuk mengetahui data awal sebelum penelitian penulis mengadakan studi pendahuluan dengan responden sebanyak 10 orang dan menunjukkan hasil bahwa ibu yang pengetahuannya baik 6 orang atau $60 \%$ dan 5 orang $(50 \%)$ status gizi balitanya baik, demikian pula dari 7 orang (70\%) Ibu yang melaksanakan pola asuh baik, sebagian besar yaitu berjumlah 6 orang $(60 \%)$ status gizi balitanya baik, dari kedua variabel dengan katagori baik tersebut tidak ada sama sekali yang balitanya mengalami kasus gizi buruk ( 0 \%). Berdasarkan latar belakang dan permasalahan tersebut peneliti bermaksud untuk mengadakan penelitian tentang a. Uji beda beda kelompok berhubungan ( $U j i$ Paired Sample t-test)
"Pengaruh Pengetahuan Dan Pola Asuh Ibu Terhadap Status Gizi Balita Di Posyandu Tunas Melati Desa Limbung Kecamatan Sungai Raya Kabupaten Kubu Raya Tahun 2020”.

\section{Metode}

Desain penelitian yang digunakan adalah Quasi Eksperimental, dengan desain yang digunakan adalah One group pre test-post tes, untuk mengetahui pengaruh penyuluhan terhadap pengetahuan tentang gizi dan pola asuh. Rancangan ini tidak ada kelompok pembanding (Kontrol), tetapi dengan pre test yang memungkinkan peneliti dapat menguji perubahan pengetahuan yang terjadi setelahada perlakuan. Pendekatan yang digunakan untuk mengukur pengetahuan dan pola asuh ibu adalah pendekatan cross sectional. Populasi penelitian disini adalah seluruh Ibu yang mempunyai Balita dan berkunjung ke Posyandu Tunas melati sebanyak 115 orang. Sampel yang diambil yaitu sebanyak 53 orang.

\section{Hasil dan Pembahasan}

1. Perbedaan pengetahuan ibu tentang Gizi sebelum dan sesudah penyuluhan

Tabel 2. Pengaruh Pengetahuan Ibu Tentang Gizi Seimbang Sebelum Dan Sesudah Penyuluhan

\begin{tabular}{cccccc}
\hline Variabel & SD & t hitung & t Tabel & Df & P-value \\
\hline $\begin{array}{c}\text { Pair 1 Pengetahuan } \\
\text { sebelum - sesudah } \\
\text { Penyuluhan }\end{array}$ & 0,558 & 4.677 & 2021 & 52 & 0,00 \\
\hline
\end{tabular}




\section{Hasil Uji Paired Sample t-test} diketahui bahwa hasil $t$ hitung adalah 4677 lebih besar dari t tabel adalah 2021 dan nilai signifikansi (nilai $\mathrm{p}=0,00$ ) sehingga $\mathrm{p}<0,05(\alpha)$ maka Ha diterima dan Ho ditolak artinya ada pengaruh antara pengetahuan ibu tentang gizi sebelum pemberian penyuluhan dengan sesudah penyuluhan. Dimana dengan harga positif (+) menunjukkan pengetahuan ibu tentang gizi sebelum pemberian penyuluhan lebih kecil dari pengetahuan sesudah pemberian penyuluhan, sehingga pemberian penyuluhan lebih efektif untuk meningkatkan pengetahuan ibu tentang gizi di Posyandu Tunas Melati.

2. Perbedaan Pola Asuh Ibu sebelum dan sesudah penyuluhan

Tabel 3. Perbedaan Pola Asuh Ibu Sebelum dan Sesudah Penyuluhan

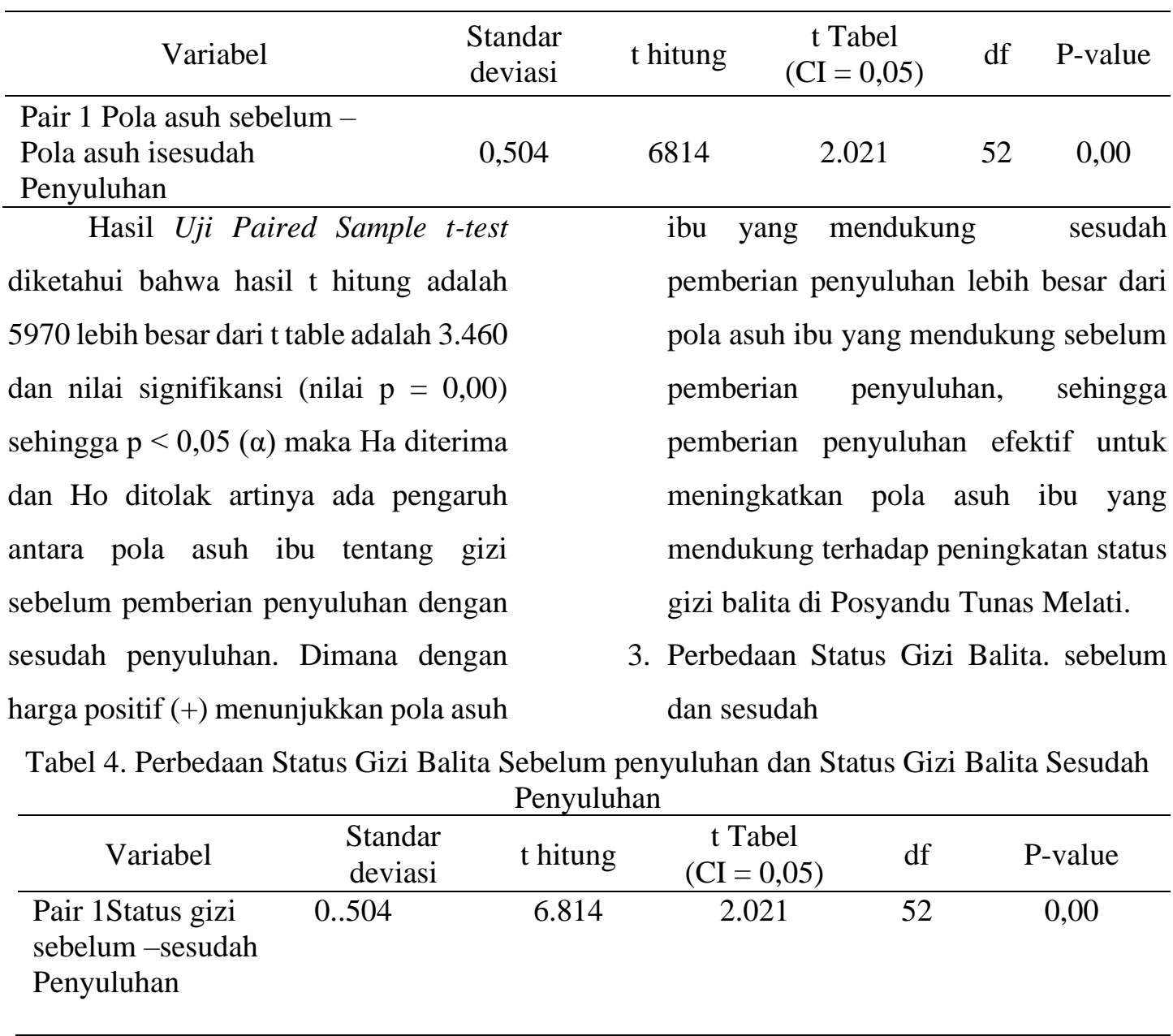

Hasil Uji Paired Sample t-test diketahui bahwa hasil t hitung adalah 5970 lebih besar dari t table adalah 3.460 dan nilai signifikansi (nilai $\mathrm{p}=0,00$ ) sehingga $\mathrm{p}<0,05(\alpha)$ maka Ha diterima dan Ho ditolak artinya ada perbedaan rata-rata antara status gizi balita sebelum pemberian penyuluhan dengan 
sesudah penyuluhan. Dimana dengan harga Positif (+) menunjukkan status gizi baik sesudah pemberian penyuluhan lebih besar dari status gizi baik sebelum

b. Uji Regresi linier (Linier Regression)

pemberian penyuluhan, sehingga pemberian penyuluhan efektif untuk meningkatkan status gizi balita. di Posyandu Tunas Melati.

1. Pengaruh pendidikan terhadap Status Gizi balita

Tabel 5. Pengaruh Pendidikan Ibu Terhadap Status Gizi balita

\begin{tabular}{cccccc|c}
\hline \multirow{2}{*}{ Model } & \multicolumn{2}{c}{ Unstandardized } & \multicolumn{2}{c|}{$\begin{array}{c}\text { Standardized } \\
\text { Coefficients }\end{array}$} & \multirow{2}{*}{ Sig } \\
\cline { 3 - 5 } & & B & Std. Error & Beta & & \\
\cline { 3 - 5 } & (Constant) & .655 & .071 & & 9,194 & .000 \\
& Pendidikan & .303 & .106 & .372 & 2.863 & .006 \\
\hline
\end{tabular}

Terlihat pada tabel 5. Hasil uji statistic pengaruh pendidikan responden terhadap status gizi balita menunjukkan bahwa nilai sig 0,006 nilai sig lebih kecil dari nilai probabilitas sebesar 0,05 , atau nilai $0,006<0,05$, maka $\mathrm{H}_{\mathrm{a}}$ diterima dan Ho ditolak. Variabel Pola asuh ibu mempunyai thitung yakni 2.863 dengan $\mathrm{t}_{\text {tabel }}=2,021$. Jadi $\quad \mathrm{t}_{\text {hitung }}>\mathrm{t}_{\text {tabel }} \quad$ dapat

2. Pengaruh Pekerjaan terhadap Status

Gizi balita disimpulkan bahwa variabel Pendidikan ibu memiliki kontribusi terhadap status gizi balita. Nilai t positif menunjukkan bahwa variabel pendidikan ibu tentang gizi mempunyai hubungan yang searah dengan status gizi balita. Jadi dapat disimpulkan Pola asuh ibu tentang gizi memiliki pengaruh terhadap status gizi balita

Tabel 6. Pengaruh Pekerjaan Ibu Terhadap Status Gizi balita

\begin{tabular}{llccccc}
\hline \multirow{2}{*}{ Model } & \multicolumn{2}{c}{ Unstandardized } & \multicolumn{2}{c}{$\begin{array}{c}\text { Standardized } \\
\text { Coefficients }\end{array}$} & \multirow{2}{*}{ Coefficients } & \multirow{2}{*}{ Sig } \\
\cline { 3 - 5 } & & $\mathrm{B}$ & Std. Error & Beta & & \\
\hline \multirow{2}{*}{1} & (Constant) & .706 & .068 & & 10,388 & .000 \\
& pekerjaan & .241 & .113 & .286 & 2.183 & .038 \\
\hline
\end{tabular}

Terlihat pada tabel 6. terdapat nilai sig 0,038 Nilai sig lebih kecil dari nilai probabilitas 0,05 , atau nilai $0,038<0,05$, maka $\mathrm{H}_{\mathrm{a}}$ diterima dan $\mathrm{Ho}$ ditolak. Variabel Pekerjaan ibu mempunyai $\mathrm{t}_{\text {hitung }}$ yakni 2.183 dengan $t_{\text {tabel }}=2,021$. Jadi $\quad t_{\text {hitung }}>t_{\text {tabel }}$ artinya bahwa variabel pekerjaan ibu memiliki kontribusi terhadap status gizi balita. Nilai $\mathrm{t}$ positif menunjukkan bahwa pekerjaan ibu tentang gizi mempunyai hubungan yang searah dengan status gizi balita. Jadi dapat disimpulkan Pekerjaan ibu memiliki pengaruh terhadap status gizi balita. 
3. Pengaruh Pendapatan terhadap Status

Gizi balita

Tabel 7. Pengaruh Pendapatan Responden terhadap Status Gizi balita

\begin{tabular}{llccccc}
\hline \multirow{2}{*}{ Model } & \multicolumn{2}{c}{$\begin{array}{c}\text { Unstandardized } \\
\text { Coefficients }\end{array}$} & $\begin{array}{c}\text { Standardized } \\
\text { Coefficients }\end{array}$ & \multirow{2}{*}{$\mathrm{t}$} & \multirow{2}{*}{ Sig } \\
\cline { 3 - 5 } & & $\mathrm{B}$ & Std. Error & Beta & & \\
\hline \multirow{2}{*}{1} & (Constant) & .781 & .073 & & 10,696 & .000 \\
& Pendidikan & .028 & .116 & .034 & -.244 & .808 \\
\hline
\end{tabular}

Terlihat pada tabel 7. terdapat nilai sig 0,808 , Nilai sig lebih besar dari nilai probabilitas 0,05 , atau nilai $0,808>0,05$, maka $\mathrm{H}_{\mathrm{a}}$ ditolak. dan Ho diterima Variabel pendapatan mempunyai $\mathrm{t}_{\text {hitung }}$ yakni 0,244 dengan $t_{\text {tabel}}=2,021$. Jadi $t_{\text {hitung }}<t_{\text {tabel }}$ dapat disimpulkan bahwa variabel Pekerjaan tidak memiliki kontribusi terhadap status gizi balita. Nilai $\mathrm{t}$ negatif menunjukkan bahwa variabel Pendapatan mempunyai hubungan yang berlawanan arah dengan dengan status gizi balita. Jadi dapat disimpulkan Pendapatan tidak berpengaruh signifikan terhadap status gizi balita

4. Pengaruh Pengetahuan ibu tentang gizi terhadap Status Gizi balita

Tabel 8. Pengaruh Pengetahuan ibu tentang gizi terhadap Status Gizi Balita

\begin{tabular}{|c|c|c|c|c|c|c|}
\hline & \multirow[t]{2}{*}{ Model } & \multicolumn{2}{|c|}{$\begin{array}{l}\text { Unstandardized } \\
\text { Coefficients }\end{array}$} & \multirow{2}{*}{$\begin{array}{c}\text { standardized } \\
\text { Coefficients } \\
\text { Beta }\end{array}$} & \multirow[t]{2}{*}{$\mathrm{t}$} & \multirow[t]{2}{*}{ Sig } \\
\hline & & B & Std. Error & & & \\
\hline \multirow[t]{2}{*}{1} & (Constant) & 250 & .082 & & 3035 & .004 \\
\hline & $\begin{array}{l}\text { Pengetahuan } \\
\text { ibu }\end{array}$ & .701 & .094 & 724 & 7487 & .000 \\
\hline
\end{tabular}

Terlihat pada kolom Coefficients model 1 terdapat nilai sig 0,000 Nilai sig lebih kecil dari nilai probabilitas 0,05 , atau nilai $\mathrm{p}=0,002<0,05$, maka $\mathrm{H}_{\mathrm{a}}$ diterima dan Ho ditolak. Variabel Pengetahuan ibu tentang gizi mempunyai $t_{\text {hitung }}$ yakni 7,487 dengan $t_{\text {tabel }}=2,021$. Jadi $t_{\text {hitung }}>t_{\text {tabel }}$ dapat disimpulkan bahwa variabel Pengetahuan ibu tentang gizi

5. Pengaruh Pola asuh terhadap Status

Gizi balita memiliki kontribusi terhadap status gizi balita. Nilai t positif menunjukkan bahwa variabel Pengetahuan ibu tentang gizi mempunyai hubungan yang searah dengan status gizi balita. Jadi dapat disimpulkan Pengetahuan ibu tentang gizi memiliki pengaruh signifikan terhadap status gizi balita. 
Tabel 9. Pengaruh Pola asuh ibu tentang gizi terhadap Status Gizi balita

\begin{tabular}{|c|c|c|c|c|c|c|}
\hline & \multirow{2}{*}{ Model } & \multicolumn{2}{|c|}{$\begin{array}{l}\text { Unstandardized } \\
\text { Coefficients }\end{array}$} & $\begin{array}{c}\text { Standardized } \\
\text { Coefficients }\end{array}$ & \multirow[t]{2}{*}{$\mathrm{t}$} & \multirow{2}{*}{ Sig } \\
\hline & & B & Std. Error & Beta & & \\
\hline \multirow[t]{2}{*}{1} & (Constant) & .500 & .077 & & 6.536 & .000 \\
\hline & Pola Asuh & .470 & .097 & .561 & 4.845 & .000 \\
\hline
\end{tabular}

Terlihat pada table 9. terdapat nilai sig 0,000 Nilai sig lebih kecil dari nilai probabilitas 0,05 , atau nilai $0,000<0,05$, maka $\mathrm{H}_{\mathrm{a}}$ diterima dan Ho ditolak. Variabel Pola asuh ibu mempunyai $t_{\text {hitung }}$ yakni 4.845 dengan $t_{\text {tabel }}=2,021$. Jadi $\mathrm{t}_{\text {hitung }}>\mathrm{t}_{\text {tabel }}$ dapat disimpulkan bahwa variabel Pola asuh ibu memiliki kontribusi terhadap status gizi balita. Nilai t positif menunjukkan bahwa variabel Pola asuh ibu tentang gizi mempunyai hubungan yang searah dengan status gizi balita. Jadi dapat disimpulkan Pola asuh ibu tentang gizi memiliki pengaruh signifikan terhadap status gizi balita. c. Uji Regresi Linear Ganda (Multiple Linier Regression)

1. Menggunakan Uji t.

Untuk mengetahui Pengetahuan dan Pola asuh ibu serta pendidikan, dan pendapatan responden secara parsial berpengaruh nyata terhadap status gizi balita menggunakan Uji t Derajat signifikansi yang digunakan adalah 0,05 . Apabila nilai signifikan lebih kecil dari derajat kepercayaan maka kita menerima hipotesis alternative. Hasil uji t pada penelitian ini adalah sebagai berikut.

Tabel 10. Variabel Yang Paling Berpengaruh terhadap Status Gizi Balita

\begin{tabular}{ccccccc}
\hline \multirow{2}{*}{ Model } & \multicolumn{2}{c}{$\begin{array}{c}\text { Unstandardized } \\
\text { Coefficients }\end{array}$} & $\begin{array}{c}\text { Standardized } \\
\text { Coefficients }\end{array}$ & \multirow{2}{*}{$\mathrm{t}$} & \multirow{2}{*}{ Sig } \\
\cline { 3 - 5 } & & $\mathrm{B}$ & Std. Error & Beta & & \\
\hline 1 & (Constant) & .781 & .073 & & 3.035 & .004 \\
& Pengetahuan & .028 & .116 & .724 & 7.487 & .000 \\
2 & (Constant) & .184 & .078 & & 2.349 & .023 \\
& Pengetahuan & .574 & .095 & -593 & 6.069 & .000 \\
& Pola asuh & .263 & .082 & -315 & 3.225 & .002 \\
\hline
\end{tabular}

Terlihat pada Tabel 16. hasil analisa model stepwise pada model 1 diketahui bahwa variabel yang paling berpengaruh terhadap status gizi balita adalah pengetahuan ibu dimana pengetahuan ibu mempunyai nilai sig 0,000 sedangkan Pola Asuh ibu mempunyai nilai sig 0,02 dan nilai $t$ untuk pengetahuan ibu adalah 6.069 sedangkan nilai $\mathrm{t}$ Pola asuh ibu adalah 3.225, Adapun nilai koefisien regresi untuk Pengetahuan ibu adalah 0,574 dan untuk Pola asuh ibu adalah 0,263. Sehingga dapat disimpulkan bahwa berdasarkan nilai t Pengetahuan ibu lebih berpengaruh terhadap status gizi balita 
dari pada pola asuh ibu. maka untuk rumus regresi yang dibentuk seperti persamaan dibawah ini:

2. Hasil Uji F

Untuk melihat pengaruh Pengetahuan, Pola asuh ibu, Pendidikan, Pekerjaan dan

Tabel 11. Pengaruh Secara Simultan Pengetahuan, Pola Asuh Ibu Dan Pendidikan, Pekerjaan dan Pendapatan Responden Terhadap Status Gizi Balita

\begin{tabular}{|ll|r|r|r|r|r|}
\multicolumn{2}{|c|}{} & & Sum of & & & \\
Model & & Squares & df & Mean Square & F & Sig. \\
\hline 1 & Regression & 4.565 & 1 & 4.565 & 56.061 & $.000^{\mathrm{a}}$ \\
& Residual & 4.152 & 51 & .081 & & \\
& Total & 8.717 & 52 & & & \\
\hline 2 & Regression & 5.279 & 2 & 2.640 & 38.396 & $.000^{\mathrm{b}}$ \\
& Residual & 3.438 & 50 & .069 & & \\
& Total & 8.717 & 52 & & &
\end{tabular}

Pengujian secara simultan

Pengetahuan dan pola asuh responden terhadap status gizi balita menunjukkan bahwa darii Tabel 11. hasil uji $\mathrm{F}$ pada "Anova" model 2 diperoleh nilai $F_{\text {hitung }}$ sebesar 38,396 dengan nilai sig $=0,000$. Sehingga nilai $F_{\text {hitung }}(38,396)>F_{\text {tabel }}(3,61)$,
Pendapatan responden terhadap status gizi balita adalah menggunakan Uji $\mathrm{F}$ (Uji Regresi linier berganda). Hasil uji F pada penelitian ini dapat dilihat pada tabel berikut: dan nilai sig. lebih kecil dari nilai probabilitas 0,05 atau nilai $0,000<0,05$; maka $\mathrm{H}_{0}$ diterima, berarti secara bersamasama (simultan) Pengetahuan dan Pola asuh ibu berpengaruh signifikan terhadap status gizi balita.

3. Hasil Uji Koefisien determinasi $\left(\mathrm{R}^{2}\right)$

\section{Tabel 12. Kontribusi Pengetahuan, Pola Asuh Ibu Dan Pekerjaan Terhadap Status Gizi}

\begin{tabular}{|l|r|r|r|r|}
\hline Model & R & R Square & \multicolumn{1}{c|}{$\begin{array}{c}\text { Adjusted R } \\
\text { Square }\end{array}$} & $\begin{array}{c}\text { Std. Error of } \\
\text { the Estimate }\end{array}$ \\
\hline 1 & $.724(\mathrm{a})$ & .524 & .514 & .285 \\
2 & $.778(\mathrm{~b})$ & .606 & .590 & .262 \\
\hline
\end{tabular}

Berdasarkan Tabel 12 dapat disimpulkan bahwa Pengetahuan ibu tentang Gizi sesudah penyuluhan dan Pola asuh ibu sesudah penyuluhan berpengaruh sebesar 60,6\% terhadap Status gizi balita, sedangkan $39,4 \%$ dipengaruhi variabel lain yang tidak diteliti. Karena nilai $\mathrm{R}$ Square diatas $50 \%$ atau cenderung mendekati nilai 1 maka dapat disimpulkan 
Pengaruh Pengetahuan Ibu Sebelum Dan

\section{Sesudah Penyuluhan}

Dari hasil Uji Paired Sample t-test diketahui bahwa hasil t hitung adalah -4677 lebih besar dari $\mathrm{t}$ tabel adalah 2021 dan nilai signifikansi (nilai $\mathrm{p}=0,00$ ) sehingga $\mathrm{p}<0,05$ $(\alpha)$ maka Ho ditolak artinya ada pengaruh antara pengetahuan ibu tentang gizi sebelum pemberian penyuluhan dengan sesudah penyuluhan. Dimana dengan harga positif $(+)$ menunjukkan pengetahuan ibu tentang gizi yang baik sebelum pemberian penyuluhan lebih kecil dari pengetahuan ibu tentang Gizi yang baik sesudah pemberian penyuluhan, sehingga pemberian penyuluhan efektif untuk meningkatkan pengetahuan ibu tentang gizi di Posyandu Tunas Melati.

Pengetahuan ibu dapat mempengaruhi perilaku ibu akan menjadi lebih baik karena dengan pemberian penyuluhan berarti memberikan pendidikan kepada ibu tentang gizi balita dan asupan gizi seimbang sehingga dapat berdampak pada perubahan perilaku positif dalam upaya peningkatan status gizi balita hal ini sesuai dengan hasil penelitian Ogunba (2006) menyebutkan bahwa perilaku ibu yang benar selama memberi makan akan meningkatkan konsumsi pangan anak dan pada akhirnya akan meningkatkan status gizi anak.

\section{Pengaruh pola asuh ibu sebelum dan sesudah penyuluhan}

Hasil Uji Paired Sample t-test diketahui bahwa hasil t hitung adalah 5970 lebih besar dari t table yaitu 3.460 dan nilai signifikansi (nilai $\mathrm{p}=0,00)$ sehingga $\mathrm{p}<0,05(\alpha)$ maka Ho ditolak artinya ada pengaruh antara pola asuh ibu tentang gizi sebelum pemberian penyuluhan dengan sesudah penyuluhan. Dimana dengan harga positif (+) menunjukkan sesudah pemberian penyuluhan pola asuh ibu yang mendukung lebih besar dari pola asuh ibu yang mendukung sebelum pemberian penyuluhan, sehingga pemberian penyuluhan efektif untuk meningkatkan pola asuh ibu yang mendukung terhadap peningkatan status gizi balita di Posyandu Tunas Melati.

Hal ini sejalan dengan kerangka konseptual yang dikemukan oleh UNICEF yang dikembangkan lebih lanjut oleh Engle et al (1997) menekankan bahwa tiga komponen makanan - kesehatan - asuhan merupakan faktor-faktor yang berperan dalam menunjang pertumbuhan dan perkembangan anak yang optimal dengan menerapkan pola asuh yang melipui pola suh makan dan pola asuh kesehatan.

Pola asuh yang tidak mendukung dapat mengakibatkan rendahnya konsumsi nutrisi pada balita sehingga dapat menyebabkan terjadinya gizi kurang. Agar pola asuh makan dapat diterapkan secara optimal maka ibu harus memahami dan mengerti tentang pola asuh yang benar. Untuk mencapai hal tersebut perlu pembelajaran secara berkesinambungan diantaranya adalah melalui kegiatan penyuluhan dan pembelajaran.

Pengaruh Status Gizi Balita Sebelum Dan Sesudah Penyuluhan

Hasil Uji Paired Sample t-test diketahui bahwa hasil t hitung adalah -5970 lebih besar 
dari t table adalah 3.460 dan nilai signifikansi (nilai $p=0,00$ ) sehingga $p<0,05(\alpha)$ maka Ho ditolak artinya ada pengaruh rata-rata antara status gizi balita sebelum pemberian penyuluhan dengan sesudah penyuluhan. Dimana dengan harga positif (+) menunjukkan status gizi baik sesudah pemberian penyuluhan lebih besar dari status gizi baik sebelum pemberian penyuluhan, sehingga pemberian penyuluhan efektif untuk meningkatkan status gizi balita. di Posyandu Tunas Melati.

Anak balita merupakan konsumen pasif yang sangat bergantung pada orangtuanya, terutama ibu, dalam menerima apa yang dikonsumsi. Sebagai gate keeper, yaitu orang yang menentukan bahan makanan yang dibeli dan bagaimana bahan makanan tersebut disiapkan, ibu sangat berperan dalam menentukan keadaan gizi anak (Karyadi 1985). Perilaku konsumsi yang salah menyebabkan rendahnya konsumsi pangan dan mempengaruhi status gizi anak., maka dengan penyuluhan dapat meningkatkan pengetahuan ibu sehingga dapat memperbaiki perilaku konsumsi makan yang salah sehingga berdampak pada peningkatan status gizi balita.

\section{Pengaruh Pengetahuan Ibu Terhadap Status Gizi Balita}

Dari hasil uji regresi linier terdapat nilai sig 0,000 yaitu nilai sig lebih kecil dari nilai probabilitas $0,05,(0,000<0,05)$, maka $\mathrm{H}_{\mathrm{a}}$ diterima dan Ho ditolak. Dan Variabel Pengetahuan ibu tentang gizi mempunyai $t_{\text {hitung }}$ yakni 7,487 dengan $t_{\text {tabel }}=2,021$. Jadi $t_{\text {hitung }}>t_{\text {tabel }}$ dapat disimpulkan bahwa variabel Pengetahuan ibu tentang gizi memiliki kontribusi terhadap status gizi balita. Nilai $\mathrm{t}$ positif menunjukkan bahwa variabel Pengetahuan ibu tentang gizi mempunyai hubungan yang searah dengan status gizi balita. Jadi dapat disimpulkan Pengetahuan ibu tentang gizi memiliki pengaruh signifikan terhadap status gizi balita.

Hal ini sejalan dengan pendapat Engle, Menon dan Haddad (1997) menambahkan bahwa tingkat pendidikan dan pengetahuan gizi mempunyai hubungan positif yang kuat dengan kesehatan dan gizi anak, terutama tingkat pendidikan dan pengetahuan gizi ibu. Ibu dengan tingkat pengetahuan gizi sedang (60-80\%) berpeluang 5.5 kali memiliki anak balita malnutrisi $(\mathrm{BB} / \mathrm{U})$ dibandingkan ibu dengan tingkat pengetahuan gizi baik (>80\%).

\section{Pengaruh Pola Asuh Ibu Terhadap Status}

\section{Gizi Balita}

Hasil uji regresi linier terdapat nilai sig 0,000 Nilai sig lebih kecil dari nilai probabilitas 0,05 , atau nilai $0,000<0,05$, maka $\mathrm{H}_{1}$ diterima dan Ho ditolak. Variabel Pola asuh ibu mempunyai $t_{\text {hitung }}$ yakni 4.845 dengan $\mathrm{t}_{\text {tabel }}=2,021$. Jadi $\mathrm{t}_{\text {hitung }}>\mathrm{t}_{\text {tabel }}$ dapat disimpulkan bahwa variabel Pola asuh ibu memiliki kontribusi terhadap status gizi balita. Nilai $t$ positif menunjukkan bahwa variabel Pola asuh ibu tentang gizi mempunyai hubungan yang searah dengan status gizi balita. Jadi dapat disimpulkan Pola asuh ibu tentang gizi memiliki pengaruh signifikan terhadap status gizi balita. 
Hal ini sesuai dengan Menurut Hetherington dan Pork (1986) dalam Briawan dan Herawati (2005), cara pengasuhan anak ditentukan oleh faktor keluarga. Sebagai orang terdekat, ibu sangat berperan dalam pengasuhan anak. Pemberian makan (feeding) dan perawatan (caring) dapat mempengaruhi tumbuh kembang anak, baik secara positif maupun negatif (Fitriana, Hartoyo \& Nasoetion 2007).

\section{Pengaruh Pendidikan Ibu Terhadap Status}

\section{Gizi Balita}

Hasil uji statistiik terdapat nilai sig 0,006 Nilai sig lebih kecil dari nilai probabilitas 0,05 , atau nilai $0,006<0,05$, maka $\mathrm{H}_{1}$ diterima dan Ho ditolak. Variabel Pola asuh ibu mempunyai thitung yakni 2.863 dengan $t_{\text {tabel }}=2,021$. Jadi $t_{\text {hitung }}>t_{\text {tabel }}$ dapat disimpulkan bahwa variabel Pendidikan ibu memiliki kontribusi terhadap status gizi balita. Nilai t positif menunjukkan bahwa variabel pendidikan ibu tentang gizi mempunyai hubungan yang searah dengan status gizi balita. Jadi dapat disimpulkan Pola asuh ibu tentang gizi memiliki pengaruh terhadap status gizi balita

Hasil penelitian ini sejalan dengan pendapat Supariasa, Bakri dan Fajar (2002), pendidikan merupakan salah satu faktor yang ikut mempengaruhi tumbuh kembang anak. Tingkat pendidikan yang lebih tinggi akan memudahkan seseorang atau masyarakat untuk menyerap informasi dan mengimplementasikannya dalam perilaku dan gaya hidup sehari-hari, khususnya dalam hal kesehatan dan gizi. Ibu dengan tingkat pendidikan dasar (tamat SD/SMP/sederajat) berpeluang memiliki anak balita malnutrisi (BB/U) 2.4 kali dibandingkan ibu dengan tingkat pendidikan Menengah (tamat SMU/sederajat ke atas).

\section{Pengaruh Pekerjaan Ibu Terhadap Status} Gizi Balita

Hasil uji statistik terdapat nilai sig 0,038 Nilai sig lebih kecil dari nilai probabilitas 0,05 , atau nilai $0,038<0,05$, maka $\mathrm{H}_{1}$ diterima dan $\mathrm{Ho}$ ditolak. Variabel Pekerjaan ibu mempunyai $t_{\text {hitung }}$ yakni 2.183 dengan $t_{\text {tabel }}=2,021$. Jadi $t_{\text {hitung }}>t_{\text {tabel }}$ dapat disimpulkan bahwa variabel pekerjaan ibu memiliki kontribusi terhadap status gizi balita. Nilai $t$ positif menunjukkan bahwa variabel pendidikan ibu tentang gizi mempunyai hubungan yang searah dengan status gizi balita. Jadi dapat disimpulkan Pekerjaan ibu memiliki pengaruh terhadap status gizi balita

Hasil tersebut sesuai dengan pendapat Sukarni (1994) yang menyatakan bahwa Pekerjaan memiliki hubungan yang erat dengan pendidikan dan pendapatan serta memiliki keterkaitan dengan faktor lain, seperti kesehatan, status gizi dan lainnya. Ayah yang bekerja sebagai petani dan buruh berpeluang 2.3 kali dan 3.2 kali memiliki anak balita malnutrisi $(\mathrm{BB} / \mathrm{U}, \mathrm{TB} / \mathrm{U}$ dan $\mathrm{BB} / \mathrm{TB})$ dibandingkan ayah yang berkerja sebagai karyawan, wirausaha atau pedagang. Hal ini terkait dengan jumlah pendapatan keluarga yang diperoleh.

Pengaruh Pendapatan Ibu Terhadap Status Gizi Balita 
Hasil uji statistic terdapat nilai sig 0,808, Nilai sig lebih besar dari nilai probabilitas 0,05 , atau nilai $0,808>0,05$, maka $\mathrm{H}_{1}$ ditolak. dan $\mathrm{Ho}$ diterima Variabel pendapatan mempunyai thitung yakni 0,244 dengan $t_{\text {tabel }}=2,021$. Jadi $t_{\text {hitung }}<t_{\text {tabel }}$ dapat disimpulkan bahwa variabel Pekerjaan tidak memiliki kontribusi terhadap status gizi balita. Nilai t negatif menunjukkan bahwa variabel Pendapatan mempunyai hubungan yang berlawanan arah dengan dengan status gizi balita. Jadi dapat disimpulkan Pendapatan tidak berpengaruh signifikan terhadap status gizi balita

Menurut Khomsan (2003), anak-anak yang berasal dari keluarga berpenghasilan rendah sangat rawan terhadap gizi kurang. Anak-anak tersebut cenderung mengkonsumsi energi dan protein lebih rendah daripada anakanak yang berasal dari keluarga kaya. Namun, anak balita di daerah penelitian pada umumnya menjadi prioritas pertama dalam pembagian makanan dalam keluarga, sehingga kondisi ekonomi dan tingkat ketahanan pangan rumah tangga diduga kurang berpengaruh terhadap perubahan konsumsi pangan dan status gizi anak balita. Faktor yang memiliki pengaruh terhadap status gizi (TB/U) anak balita adalah pengetahuan dan pola asuh.

\section{Variabel yang paling berpengaruh terhadap status gizi balita}

Dari empat variabel yang diikutkan pada uji statistic yaitu pengetahuan ibu tentang gizi, pola asuh ibu, pemdidikan dan pekerjaan ibu maka hasil analisa model stepwise diketahui bahwa variabel pengetahuan ibu mempunyai nilai sig 0,000, dan Pola Asuh ibu mempunyai nilai sig 0,02, namun angka $t$ untuk pengetahuan ibu adalah 6.069 dan Pola asuh adalah 3.225, koefisien regresi untuk Pengetahuan ibu adalh 0,574 dan untuk Pola asuh adalah 0,263. sehingga dapat disimpulkan bahwa berdasarkan nilai $\mathrm{t}$ pengetahuan ibu lebih berpengaruh dari pola asuh ibu terhadap status gizi balita.

Sebagaimana yang diungkapkan Sandjaja (2000) bahwa faktor pola asuh yang berperan terhadap status gizi anak balita antara lain akibat dari adanya paparan ibu terhadap media massa dan penyuluhan gizi secara teratur sehingga meningkatkan pengetahuan ibu dan berpengaruh terhadap pola asuh ibu yang berperan terhadap status gizi balita. Demikian juga Hasil penelitian Yulia (2008) menemukan bahwa tingkat kecukupan energi dan protein anak balita akan semakin meningkat, jika pengetahuan ibu tentang gizi baik sehingga pola asuh makan yang diberikan ibu semakin baik. Tingkat kecukupan zat gizi mempengaruhi status gizi (BB/U dan BB/TB), yang berarti penurunan atau peningkatan konsumsi pangan akan berdampak langsung terhadap berat badan anak balita. Anak balita yang mengalami defisit energi tingkat berat (TKE <70\%) berpeluang 3.3 kali mengalami malnutrisi (BB/TB) dibandingkan anak balita dengan kecukupan energi cukup (TKE >90\%). Begitu pula dengan anak balita yang mengalami defisit protein tingkat sedang (TKP 70-90\%) berpeluang 2.6 kali mengalami malnutrisi 
(BB/U) dibandingkan anak balita dengan kecukupan protein cukup (TKP >90\%). Oleh karena itu salah satu upaya untuk meningkatkan status gizi balita adalah dengan meningkatkan pengetahuan ibu tentang gizi dan penerapan pola asuh makan.

Hal ini dapat dilakukan dengan meningkatkan penyuluhan tentang gizi kepada masyarakat terutama kepada ibu yang mempunyai balita dengan harapan masyarakat memahami dan mampu melaksanakan pemenuhan kebutuhan gizi keluarganya terutama bagi anak balita. Posyandu merupakan tempat pelayanan yang paling efektif untuk melakukan pendidikan kesehatan terutama upaya peningkatan status gizi balita. Oleh karena itu peran kader di meja IV sangat strategis dalam upaya tersebut sehingga perlu adanya peningkatan kader posyandu agar mampu memberikan penyuluhan gizi secara berkesinambungan dengan harapan bahwa melalui penyuluhan yang berkesinambungan dan sesuai kebutuhan serta masalah yang ada dapat meningkatkan pengetahuan dan pola asuh ibu sehingga dapat mencapai status gizi balita secara optimal dan dapat mempersiapkan sumber daya manusia yang berkualitas.

\section{Kesimpulan}

Berdasarkan nilai t Pengetahuan ibu lebih berpengaruh dari pola asuh ibu terhadap status gizi balita. maka untuk persamaan regresi yang dibentuk adalah sebagai berikut: $\mathrm{Y}=0,184+0,574 \mathrm{X}_{1}+0,263 \mathrm{X}_{2}$. Bagi petugas kesehatan di harapkan dapat memberikan penyuluhan kepada ibu post partum dan lebih menekankan penyuluhan tentang materi kolostrum, kegunaan kolostrum, keuntungan dari pemberian ASI, penyakit kejang.

\section{Daftar Pustaka}

Briawan D.Herawati T. 2005. Peran anggota rumahtangga di dalam pengasuhan pertumbuhan dan perkembangan anak balita. Laporan Akhir Penelitian Studi Kajian Wanita. Bogor : Fakultas Pertanian, Institut Pertanian Bogor.

Denis. 2002. Peranan Pangan dan Gizi untuk Kualitas Hidup. Jakarta : PT Gramedia Widiasarana Indonesia.

Depkes RI. 2012. Tabel Status Gizi Depkes RI. Jakarta : BKMM Depkes RI 2018. Laporan Hasil Riskesdas 2007.Jakarta : Depkes RI.

2008. Laporan Hasil Riskesdas 2007. Jakarta : Depkes RI.

Dinkes Prop Kalbar. 2011. Profil Dinas Kesehatan Propinsi Kalimantan Barat. Pontianak : Dinkes Prop Kalbar.

Engle PL. Menon P. Haddad L. 1997. Care and Nutrition Concept and Measurement. Washington DC : International Food Policy Research Institute $<$ http://id.Wikipedia/Wiki/Bali taku> Diakses tanggal 3 September 2012 jam 15.20 WIB.

Fitriana. Hartoyo. Nasoetion A. 2007. Hubungan pola asuh, status gizi dan status kesehatan anak balita korban gempa dan tsunami di Nanggroe Aceh Darussalam.

Khomsan A. Baliwati FB, Dwiriani CM. 2004. Penilaian Status Gizi, editor. Pengantar Pangan dan Gizi. Jakarta : Penebarbit Swadaya.

Ogunba BO. 2006. Maternal behavioral feeding practices and under-five nutrition : implication for child 
development and care. Journal of Applied Sciences Researchhttp://www.library.usu.ac.id/ modules.php. Diakses 1 September 2012 Jam 11.32. WIB.

Sanjaya, W.2008. Strategi Pembelajaran. Jakarta : Penerbit Prenada Media Group.

Sari. Wina Yuliati. 2010. Hubungan Pengetahuan Ibu dan Dukungan Suami di kabupaten Banjar Negara Propinsi Jawatengah tahun 2010. Jakarta : FKUI

Sediaoetama, 2010. Ilmu Gizi untuk mahasiswa dan profesi. Jakarta: Dian Rakjat

Soetjiningsih. Tumbuh Kembang Anak. Buku Kedokteran. Jakarta : 2007.

Sukarni M. 1994. Kesehatan Keluarga dan Lingkungan. Bogor : Departemen Pendidikan dan

Supriasa dkk. 2005. Penilaian Status Gizi. Jakarta : Gramedia Pustaka

Unicef. 2017. "Buku Kader Usaha Perbaikan Gizi Keluarga". UPGK. Jakarta

World Health Organization, 2011. Making Pregnancy Safer. Available from : http://www.who.int/making_pregnancy _safer/topics/adolescent_pregnanc y/en/in dex.html. [Accesed 11 April 2012. jam 14.05]. 